\title{
SUBSTITUSI TEPUNG AMPAS KELAPA DALAM PEMBUATAN BROWNIES KUKUS TERHADAP SIFAT ORGANOLEPTIK DAN NILAI GIZI
}

\author{
Coconut Pulp Flour Subtitution in The Steamed Brownies Making With \\ Organoleptic Characteristic and Nutritional Value
}

\author{
Nurhiyanah $^{1)}$, Septiani ${ }^{1)}$ \\ ${ }^{1)}$ Program Studi S1 Gizi, Fakultas Kesehatan Masyarakat, Universitas Binawan \\ nur_hiyanah@yahoo.com; septiani@binawan.ac.id
}

\begin{abstract}
The utilization of coconut pulp flour in the food product making is still very limited. This research to analyze brownies that are distuited coconut pulp flour against nutritional value. This research is an experimental research with level of substitution of wheat flour with coconut pulp flour as treatment. There are 3 treatments, that is F1 (55\% wheat flour and 45\% coconut pulp flour), F2 (45\% wheat flour and 55\% coconut pulp flour) ad F3 (35\% wheat flour and 65\% coconut pulp flour). Formula results selected from the organoleptic test who is $F 1$ with comparison 55:45 continued with result proximate test that obtained water rate, ash rate, fat, protein, carbohydrate and fiber in way continue that $23,88 \%$, $1,91 \%, 7,39 \%, 5,78 \%, 61,04$ and 1,82\%. The conclusion of this research is that have differences ( $p$ $<0.05)$ between the formula result to water rate, ash rate, protein, carbohydrate and fiber.
\end{abstract}

Keywords: Coconut Pulp Flour, Brownies, Nutritional Value

\begin{abstract}
ABSTRAK
Pemanfaatan tepung ampas kelapa dalam pembuatan produk makanan masih sangat terbatas. Penelitian ini bertujuan untuk menganalisis brownies yang disubstitusi tepung ampas kelapa terhadap nilai gizi. Penelitian eksperimental ini menggunakan substitusi tepung terigu dengan tepung ampas kelapa sebagai perlakuan. Terdapat 3 perlakuan, yaitu F1 (55\% tepung terigu dan 45\% tepung ampas kelapa), F2 (45\% tepung terigu dan 55\% tepung ampas kelapa) dan $\mathrm{F} 3$ (35\% tepung terigu dan 65\% tepung ampas kelapa). Hasil formula terpilih dari hasil uji organoleptik yaitu F1 dengan perbandingan 55:45 dilanjutkan dengan hasil uji proksimat berupa kandungan air, abu, lemak, protein, karbohidrat dan serat kasar secara berturut-turut yaitu $23,88 \%, 1,91 \%, 7,39 \%, 5,78 \%, 61,04$ dan $1,82 \%$. Kesimpulan dari penelitian ini adalah terdapat perbedaan yang nyata $(\mathrm{p}<0,05)$ antara formula terpilih terhadap kadar air, kadar abu, protein, karbohidrat dan serat.
\end{abstract}

Kata kunci: Tepung Ampas Kelapa, Brownies, Nilai Gizi

\section{PENDAHULUAN}

Ampas kelapa merupakan hasil akhir dari pembuatan santan. Saat ini pemanfaatan ampas kelapa di kalangan masyarakat masih terbatas. Ampas kelapa memiliki kandungan gizi yang baik, terutama kandungan serat kasar yang cukup tinggi yaitu 15,07\% (Yulvianti et al, 2015). Ampas kelapa yang mengandung tinggi serat ini dapat dijadikan sebagai olahan tepung ampas kelapa yang bernilai gizi. Perluasan 
pemanfaatan ampas kelapa ini sangat menguntungkan secara ekonomi bagi petani kelapa dan produsen, serta masyarakat yang mengkonsumsinya (Kailaku et al, 2012). Ampas kelapa yang diolah menjadi tepung ampas kelapa dapat memudahkan masyarakat untuk diaplikasikan menjadi olahan pangan. Tepung ampas kelapa ini dapat digunakan sebagai bahan substitusi tepung terigu atau tepung lainnya untuk digunakan dalam pengolahan pangan.

Tepung ampas kelapa dapat dimanfaatkan sebagai bahan tambahan dalam berbagai macam pembuatan makanan dan membuat cita rasa semakin gurih, aroma yang khas serta mengandung zat gizi dan kandungan serat yang tinggi, seperti, brownies, kue kering, roti, dan sebagainya (Afrianti,et al. 2016).

Brownies merupakan salah satu makanan yang cukup digemari dan diminati oleh semua kalangan, dari mulai anak-anak, remaja, sampai lansia, terutama remaja usia 17-21 tahun yang lebih paling banyak peminatnya. Struktur brownies sama seperti cake, memiliki warna yang menarik, jika dimakan terasa lembut, lembab, dan menghasilkan cita rasa dan aroma yang baik (Kusumaningrum, Mira dan Leni, 2016).
Sebelumnya telah dilakukan penelitian mengenai "Pengaruh Perbandingan Tepung Ampas Kelapa dengan Tepung Terigu Terhadap Mutu Brownies" oleh Hasan (2018). Pada penelitiannya, Hasan (2018) membuat brownies panggang dengan substitusi tepung ampas kelapa pada perlakuan 25\%, 35\% dan 45\%. Dari penelitian tersebut, Hasan (2018) hanya melakukan penilaian terhadap daya terima oleh masyarakat dan hasilnya pada perlakuan $45 \%$ tepung ampas kelapa. Penelitian mengenai pemanfaatan tepung ampas kelapa pada pembuatan produk makanan terutama dalam pembuatan brownies kukus masih sangat terbatas.

Oleh karena itu, penulis ingin melakukan penelitian lanjutan serta melakukan inovasi dari penelitian sebelumnya mengenai substitusi tepung terigu dan tepung ampas kelapa dalam pembuatan brownies kukus. Pada penelitian kali ini, perlakuan dibuat semakin meningkat dari penelitian sebelumnya dan melakukan penilaian terhadap daya terima masyarakat serta mengidentifikasi nilai gizi yang terdapat pada brownies. 


\section{METODE}

Penelitian ini menggunakan desain eksperimental dengan pembuatan brownies dilakukan di Laboratorium Kuliner Universitas Binawan, Jakarta Timur, sedangkan analisis proksimat dan serat kasar dilaksanakan di Laboratorium Pengolahan Pangan, Program Studi Ilmu dan Teknologi Pangan, Institut Pertanian Bogor, Kota Bogor. Terdapat 3 perlakuan, yaitu F1 (55\% tepung terigu dan $45 \%$ tepung ampas kelapa), F2 (45\% tepung terigu dan 55\% tepung ampas kelapa) dan F3 (35\% tepung terigu dan $65 \%$ tepung ampas kelapa). Ketiga perlakuan tersebut diuji organoleptik dan hasil terpilihnya dilakukan pengujian analisis kadar proksimat. Penelitian ini sudah memenuhi Uji Ethical Clearance dengan nomor: B/1706/2/2019/KEPK.

\section{Pembuatan Tepung Ampas Kelapa}

Pembuatan tepung ampas kelapa dilakukan dengan cara mencuci ampas kelapa, lalu disaring dan diperas, kemudian letakkan pada loyang dan masukan ke dalam oven dengan waktu dan suhu yang sudah ditetapkan. Kemudian dikeluarkan dan tunggu 2-3 menit. Lalu diblender dan disaring dengan saringan, kemudian simpan di dalam wadah yang kedap udara (Hasan,

\section{Pembuatan Brownies Kukus}

Pembuatan brownies kukus dilakukan dengan mengaduk gula pasir dan telur lalu tambahkan coklat bubuk. Panaskan margarin dan cokelat batang hingga meleleh dan masukkan dalam loyang. Masukkan tepung terigu dan tepung ampas kelapa sesuai dengan formulasi ke dalam loyang, aduk hingga rata. Masukkan telur dan gula ke dalam adonan, aduk hingga rata. Tuang adonan ke dalam loyang cetakan yang telah dioles margarin dan diberi alas kertas roti. Adonan brownies dikukus hingga matang selama 30 menit (Hasan, 2018).

\section{HASIL DAN PEMBAHASAN}

\section{A. Uji Organoleptik Brownies Tepung Ampas Kelapa}

Formula brownies tepung ampas kelapa yang telah dibuat kemudian diuji organoleptik. Hasil dari masing-masing atribut penilaian kemudian dianalisis secara deskriptif dan statistik dengan uji beda lebih dari dua kelompok menggunakan analisis sidik ragam (ANOVA) lalu dilanjutkan dengan uji lanjut Duncan. Berikut hasil uji organoleptik (uji hedonik dan uji mutu hedonik) brownies tepung ampas kelapa akan disajikan pada Tabel 1 dan Tabel 2. 2018). 
Tabel 1. Hasil Uji Hedonik Brownies Tepung Ampas Kelapa

\begin{tabular}{cccccc}
\hline \multirow{2}{*}{ Formula } & Rasa & Tekstur & Warna & Aroma & Keseluruhan \\
\cline { 2 - 5 } & $4,57^{\mathrm{b}}$ & $4,13^{\mathrm{b}}$ & $4,07^{\mathrm{b}}$ & $4,27^{\mathrm{b}}$ & $4,26^{\mathrm{b}}$ \\
\hline F0 $(0 \%)$ & $3,87^{\mathrm{a}}$ & $3,53^{\mathrm{a}}$ & $3,60^{\mathrm{a}}$ & $4,07^{\mathrm{b}}$ & $3,76^{\mathrm{a}}$ \\
F1 (45\%) & $3,77^{\mathrm{a}}$ & $3,07^{\mathrm{a}}$ & $3,37^{\mathrm{a}}$ & $3,73^{\mathrm{a}}$ & $3,48^{\mathrm{a}}$ \\
F2 (55\%) & $3,60^{\mathrm{a}}$ & $3,23^{\mathrm{a}}$ & $3,27^{\mathrm{a}}$ & $3,73^{\mathrm{a}}$ & $3,45^{\mathrm{a}}$ \\
F3 (65\%) & \multicolumn{5}{c}{} \\
\hline Keterangan: Skala atribut yaitu 1 = sangat tidak suka hingga 5 = amat sangat suka &
\end{tabular}

Berdasarkan Tabel 1, hasil uji brownies tepung ampas kelapa F0 lanjut Duncan menunjukkan bahwa berbeda nyata dengan F1, F2dan F3 perbedaan konsentrasi uji hedonik pada terhadap atribut rasa, tekstur dan warna. formulasi brownies tepung ampas Untuk atribut aroma, F0 dan F1 tidak kelapa F1 dengan F2 dan F3 tidak berbeda nyata tetapi F2 dan F3 berbeda berbeda nyata, tetapi formulasi nyata dengan F0 dan F1

Tabel 2. Hasil uji mutu hedonik brownies tepung ampas kelapa

\begin{tabular}{ccccc}
\hline \multirow{2}{*}{ Formula } & \multicolumn{4}{c}{ Atribut } \\
\cline { 2 - 5 } & Rasa & Tekstur & Warna & Aroma \\
\hline F0 $(0 \%)$ & $4,00^{\mathrm{b}}$ & $4,40^{\mathrm{b}}$ & $4,83^{\mathrm{b}}$ & $2,70^{\mathrm{a}}$ \\
F1 (45\%) & $3,53^{\mathrm{a}}$ & $3,60^{\mathrm{a}}$ & $4,27^{\mathrm{a}}$ & $3,13^{\mathrm{a}}$ \\
F2 (55\%) & $3,47^{\mathrm{a}}$ & $3,27^{\mathrm{a}}$ & $4,37^{\mathrm{a}}$ & $3,00^{\mathrm{a}}$ \\
F3 (65\%) & $3,37^{\mathrm{a}}$ & $3,20^{\mathrm{a}}$ & $4,37^{\mathrm{a}}$ & $3,03^{\mathrm{a}}$ \\
\hline
\end{tabular}

Keterangan: Skor rasa: 1 = tidak manis hingga 5 = sangat manis; skor tekstur: 1 = sangat tidak lembut hingga 5 = sangat lembut; skor warna: $1=$ cokelat krem hingga 5 = kuning kehitaman; skor aroma: $1=$ sangat tidak wangi hingga 5 = sangat wangi. Huruf yang beda pada baris yang sama menunjukkan perbedaan yang nyata $(\mathrm{p}<0,05)$

Berdasarkan Tabel 2, hasil uji lanjut Duncan menunjukkan bahwa perbedaan konsentrasi uji mutu hedonik pada formulasi brownies tepung ampas kelapa F1 dengan F2 dan F3 tidak berbeda nyata, tetapi formulasi brownies tepung ampas kelapa F0 berbeda nyata dengan F1, F2 dan F3 terhadap atribut rasa, tekstur dan warna.
Sedangkan pada keempat formulasi brownies tepung ampas kelapa tidak memberikan perbedaan yang nyata terhadap atribut penilaian aroma.

\section{Rasa}

Berdasarkan Tabel 1, hasil penilaian organoleptik uji hedonik menunjukkan bahwa brownies tepung ampas kelapa F0 memperoleh nilai 
kesukaan tertinggi terhadap rasa yaitu 4,57 (amat sangat suka), sedangkan brownies tepung ampas kelapa F3 memperoleh nilai kesukaan terendah yaitu 3,60 (sangat suka). Semakin banyak penambahan tepung ampas kelapa, maka rasa yang disukai terhadap brownies semakin berkurang. Hal ini didukung oleh penelitian Pusuma, Yhulia dan Miftahul (2018), yang menyatakan bahwa semakin tinggi substitusi tepung ampas kelapa yang digunakan pada roti tawar, maka akan menyebabkan penurunan pada tingkat kesukaan.

Berdasarkan Tabel 2, hasil uji mutu hedonik terhadap rasa, menunjukkan brownies tepung ampas kelapa F0 dan F1 memiliki rasa cukup manis, sedangkan F2 dan F3 memiliki rasa manis. Hal ini dikarenakan perubahan rasa dipengaruhi oleh substitusi tepung ampas kelapa. Rasa manis dari brownies tepung ampas kelapa semakin berkurang seiring meningkatnya penambahan tepung ampas kelapa yang semakin banyak. Hasil penelitian ini sejalan dengan penelitian Herni, Tamrin dan Nur (2018), yang menyatakan bahwa semakin banyak penambahan tepung ampas kelapa dalam pembuatan biskuit, maka akan menyebabkan rasa yang berpasir khas kelapa karena tepung ampas kelapa mengandung serat yang cukup tinggi.

\section{Tekstur}

Berdasarkan Tabel 1, hasil penilaian organoleptik uji hedonik menunjukkan bahwa brownies tepung ampas kelapa F0 memperoleh nilai kesukaan tertinggi terhadap tekstur yaitu 4,13 (sangat suka), sedangkan brownies tepung ampas kelapa F2 memperoleh nilai kesukaan terendah yaitu 3,07 (suka). Semakin banyak penambahan tepung ampas kelapa, maka tekstur yang disukai terhadap brownies semakin berkurang. Hal ini didukung oleh penelitian Hasan (2018), yang menyatakan bahwa semakin tinggi substitusi tepung ampas kelapa yang digunakan pada brownies, maka akan menyebabkan penurunan pada tingkat kesukaan.

Berdasakan tabel 2, hasil uji mutu hedonik terhadap tekstur menunjukkan bahwa brownies tepung ampas kelapa F0 dan F1 memiliki tekstur lembut, sedangkan F2 dan F3 memiliki teksur agak lembut. Tekstur brownies tepung ampas kelapa semakin tidak lembut seiring meningkatnya penambahan tepung ampas kelapa yang semakin banyak. Hal ini disebabkan karena tepung ampas kelapa tidak mengandung 
gluten seperti yang ada pada tepung terigu, yang membuat kelembutan tekstur brownies menjadi berkurang. Penelitian ini didukung oleh penelitian Pusuma, Yhulia et al., (2018) yang menyatakan bahwa semakin banyak penambahan tepung ampas kelapa pada suatu produk, maka tekstur yang dihasilkan pada roti tawar akan semakin keras (tidak lembut).

\section{Warna}

Berdasarkan Tabel 1, hasil penilaian organoleptik uji hedonik menunjukkan bahwa brownies tepung ampas kelapa F0 memperoleh nilai kesukaan tertinggi terhadap warna yaitu 4,07 (sangat suka), sedangkan brownies tepung ampas kelapa F3 memperoleh nilai kesukaan terendah yaitu 3,27 (suka). Hasil ini didukung oleh penelitian Pusuma, Yhulia, et al. (2018), yang menyatakan bahwa semakin tinggi penambahan subtitusi tepung ampas kelapa maka tingkat kesukaan dalam atribut warna pada roti tawar akan semakin berkurang.

Berdasarkan Tabel 2, hasil uji mutu hedonik terhadap warna menunjukkan brownies tepung ampas kelapa F0 berwarna cokelat kehitaman, sedangkan F1, F2 dan F3 memiliki warna cokelat tua. Warna brownies tepung ampas kelapa semakin cokelat cerah seiring meningkatnya penambahan tepung ampas kelapa yang semakin banyak. Hal ini disebabkan karena warna pada tepung ampas kelapa lebih cerah dibanding dengan warna pada tepung terigu. Hasil penelitian ini sesuai dengan pernyataan Pusuma, Yhulia dan Miftahul (2018), yang menyatakan bahwa semakin besar jumlah substitusi tepung ampas kelapa yang digunakan, maka tingkat kecerahan pada roti tawar akan semakin tinggi atau semakin cerah.

\section{Aroma}

Berdasarkan tebel 1, hasil penilaian organoleptik uji hedonik menunjukkan bahwa brownies tepung ampas kelapa F0 memperoleh nilai kesukaan tertinggi terhadap aroma yaitu 4,27 (sangat suka), sedangkan brownies tepung ampas kelapa F2 dan F3 memperoleh nilai kesukaan terendah yaitu 3,73 (sangat suka). Hasil ini didukung oleh penelitian Pusuma, et al. (2018), yang menyatakan bahwa semakin tinggi tingkat substitusi tepung ampas kelapa maka akan menurunkan tingkat kesukaan pada produk roti tawar terhadap aroma yang dihasilkan.

Berdasarkan Tabel 2, hasil uji mutu hedonik terhadap aroma menunjukkan brownies tepung ampas kelapa F0, F1, F2 dan F3 memiliki aroma agak wangi. Brownies tepung 
ampas kelapa memiliki aroma wangi khas kelapa seiring meningkatnya penambahan tepung ampas kelapa yang semakin banyak. Hal ini diduga karena semakin banyak penambahan tepung ampas kelapa yang diberikan, maka akan menimbulkan aroma yang semakin menyengat (wangi khas kelapa). Hasil penelitian ini didukung oleh penelitian Hasan (2018), yang menyatakan bahwa aroma pada brownies dapat dilihat dari bahan-bahan yang digunakan dalam pembuatan adonan terutama tepung ampas kelapa. Karena tepung ampas kelapa dapat memberikan aroma khas kelapa yang berasal dari kelapa, sehingga brownies yang dihasilkan memiliki aroma khas kelapa.

\section{B. Hasil Analisis Proksimat Brownies} Tepung Ampas Kelapa Formula Terpilih

Analisis proksimat yang dilakukan adalah kadar air, kadar abu, lemak, protein, dan karbohidrat. Selain analisis proksimat, dilakukan analisis kadar serat. Hasil analisis proksimat brownies bahwa tidak ada perbedaan yang nyata antara formula terpilih terhadap kadar lemak, tetapi terdapat perbedaan yang nyata $(\mathrm{p}<0,05)$ antara formula terpilih terhadap kadar air, kadar abu, protein, karbohidrat dan serat (Tabel 3). Berikut hasil analisis proksimat brownies formula kontrol dan formula terpilih akan disajikan pada tabel 3 .

Tabel 3. Hasil Analisis Proksimat Brownies/100g Formula Kontrol Dan Formula Terpilih

\begin{tabular}{|c|c|c|c|}
\hline Komponen & Formula Kontrol $(\%$ b/b) & Formula Terpilih $(\% \mathrm{~b} / \mathbf{b})$ & P-value \\
\hline Kadar Air & 22,29 & 23,88 & $0,000 *$ \\
\hline Kadar Abu & 1,52 & 1,91 & $0,012 *$ \\
\hline Lemak & 7,58 & 7,39 & 0,078 \\
\hline Protein & 7,86 & 5,78 & $0,001 *$ \\
\hline Karbohidrat & 60,75 & 61,04 & $0,009 *$ \\
\hline Serat & 2,41 & 1,82 & $0,009 *$ \\
\hline
\end{tabular}

(Sumber: Data Primer)

Berdasarkan Tabel 3, didapat hasil analisis proksimat pada brownies bahwa tidak ada perbedaan yang nyata antara formula terpilih terhadap kadar lemak, tetapi terdapat perbedaan yang nyata $(\mathrm{p}<0,05)$ antara formula terpilih terhadap kadar air, kadar abu, protein, karbohidrat dan serat.

\section{Kadar Air}

Kadar air untuk formula kontrol sebanyak $22,29 \%$ sedangkan untuk formula terpilih sebanyak $23,88 \%$. Berdasarkan hasil uji beda (Independent Sample t-test), kadar air brownies tepung ampas kelapa formula kontrol berbeda nyata $(\mathrm{p}<0,05)$ dengan 
brownies tepung ampas kelapa formula terpilih. Kadar air pada F0 memiliki nilai lebih rendah dibanding $\mathrm{F} 1$ hal ini disebabkan karena perbedaan kadar air dari bahan baku dan karena tepung ampas kelapa yang digunakan dalam penelitian ini memiliki kadar air yang lebih besar daripada kadar air pada tepung terigu. Hasil penelitian Suseno (2010) menyatakan bahwa kadar air pada tepung terigu sebesar $0,01 \%$ sedangkan tepung ampas kelapa mengandung kadar air sebesar 0,33\% (Yulvianti et al, 2015). Selain itu, Polii (2017) juga menyatakan bahwa peningkatan kadar air pada tepung ampas kelapa juga disebabkan oleh proses pembuatan tepung dilakukan di ruang terbuka, sehingga tepung kelapa banyak mengabsorbsi air.

\section{Kadar Abu}

Kadar abu untuk formula kontrol sebanyak 1,52\%, sedangkan pada formula terpilih sebanyak 1,91\%. Berdasarkan hasil uji beda (Independent Sample t-test), kadar abu formula kontrol berbeda nyata $(\mathrm{p}<0,05)$ dengan brownies tepung ampas kelapa formula terpilih. Kadar abu pada formula terpilih lebih tinggi daripada formula kontrol. Peningkatan kadar abu yang terjadi disebabkan karena tepung ampas kelapa mengandung kadar abu yang cukup tinggi dibanding dengan tepung terigu. Hal ini didukung oleh penelitian Polii (2017) yang menyatakan bahwa kadar abu pada tepung ampas kelapa sebesar 1,97\%, sedangkan Suseno (2010) menyatakan bahwa tepung terigu memiliki kadar abu sebesar $0,50 \%$.

\section{Kadar Lemak}

Kadar lemak pada formula kontrol sebanyak 7,58\%, sedangkan pada formula terpilih sebanyak 7,39\%. Berdasarkan hasil uji beda (Independent Sample t-test), kadar lemak brownies tepung ampas kelapa formula kontrol tidak berbeda nyata dengan brownies tepung ampas kelapa pada formula terpilih. Kadar lemak pada formula terpilih lebih rendah daripada formula kontrol. Hal ini disebabkan karena ampas kelapa mengandung kadar serat yang cukup tinggi dibanding dengan tepung terigu, sehingga semakin tinggi kadar serat yang dikandung maka semakin rendah kadar lemak yang diperoleh. Hasil ini sejalan dengan penelitian Lubis et al (2012) yang menyatakan bahwa semakin besar bahan yang mengandung kadar serat yang tinggi, maka persentase kadar lemak semakin menurun. Penurunan kadar lemak juga dapat disebabkan oleh penambahan bahan-bahan lain dalam pembuatan produk yang tidak 
mengandung lemak, sehingga dapat menyebabkan persentase kadar lemak menjadi berkurang. Dengan memiliki kandungan lemak yang rendah memperbaiki manfaatnya bagi kesehatan. Putri (2014), menyatakan bahwa kandungan gizi pada ampas kelapa memiliki kadar lemak yang rendah sehingga cocok dikonsumsi oleh golongan konsumen dengan penyakit kegemukan (obesitas), beresiko hiperkolesterol dan jantung koroner.

\section{Kadar Protein}

Kadar protein pada pada formula kontrol sebesar $7,86 \%$ sedangkan formula terpilih yaitu $5,78 \%$. Berdasarkan hasil uji beda (Independent Sample t-test), kadar protein brownies tepung ampas kelapa formula kontrol berbeda nyata $(\mathrm{p}<0,05)$ dengan brownies tepung ampas kelapa formula terpilih. Kadar protein formula terpilih lebih rendah dibandingkan formula kontrol. Hal ini disebabkan karena tepung ampas kelapa tidak memiliki kandungan gluten, sehingga mempengaruhi kandungan protein pada tepung ampas kelapa yang menjadi lebih rendah dibanding dengan tepung terigu. Hasil ini sejalan dengan penelitian Yulvianti et al (2017), yang menyatakan bahwa kandungan protein pada tepung ampas kelapa sebesar
4,10\% sedangkan Suseno (2010) menyatakan bahwa tepung terigu mengandung protein sebesar $8,90 \%$.

\section{Kadar Karbohidrat}

Kadar karbohidrat pada formula kontrol sebesar $60,75 \%$ sedangkan pada formula terpilih sebesar $61,04 \%$. Berdasarkan hasil uji beda (Independent Sample t-test), kadar karbohidrat brownies tepung ampas formula kontrol berbeda nyata $(p<0,05)$ dengan brownies tepung ampas formula terpilih. Kadar karbohidrat formula terpilih lebih tinggi dibandingkan formula kontrol. Hal ini dikarenakan tepung ampas kelapa memiliki kandungan karbohidrat yang lebih tinggi dibandingkan dengan tepung terigu. Hasil ini sejalan dengan penelitian Rousmaliana dan Septiani (2019) yang menyatakan bahwa tepung ampas kelapa memiliki kandungan karbohidrat sebesar 82\%. Sedangkan menurut Suseno (2010), tepung terigu memiliki kandungan karbohidrat sebesar $77,3 \%$.

\section{Kadar Serat}

Kadar serat pada formula kontrol sebesar $2,41 \%$ sedangkan pada formula terpilih sebesar $1,82 \%$. Berdasarkan hasil uji beda (Independent Sample ttest), kadar serat brownies tepung ampas formula kontrol berbeda nyata 
$(\mathrm{p}<0,05)$ dengan brownies tepung ampas formula terpilih. Kadar serat formula terpilih lebih rendah dibandingkan formula kontrol. Kandungan serat brownies tepung ampas kelapa pada penelitian ini lebih rendah dibandingkan dengan kandungan serat pada brownies yang dibuat oleh Setiawati (2015). Kadar serat pada hasil penelitian ini berbeda dengan penelitian sebelumnya, karena pada saat proses pembuatan tepung ampas kelapa, terjadi dua kali perlakuan pengayakan tepung dengan jenis mesh yang berbeda yaitu ayakan mesh 50 dan ayakan mesh 70 . Sehingga kadar serat yang terdapat pada tepung ampas kelapa tidak sepenuhnya lolos pada saat penyaringan atau pengayakan yang membuat kadar serat pada tepung ampas kelapa menjadi berkurang dan memiliki kadar yang lebih sedikit.

\section{Kesimpulan}

Proporsi tepung ampas kelapa dan tepung terigu berpengaruh pada organoleptik, tetapi tidak mempengaruhi mutu hedonic brownies. Kadar lemak brownies terpilih sama dengan kontrol namun kadar air, abu, protein, karbohidrat dan serat berbeda. Formula brownies terpilih (F1) mempunyai kadar air sebesar $23,88 \%$, kadar abu sebesar 1,91\%, lemak sebesar $7,39 \%$, protein sebesar $5,78 \%$, karbohidrat sebesar $61,04 \%$ dan serat sebesar $1,82 \%$.

\section{UCAPAN TERIMA KASIH}

Ucapan terima kasih kepada Universitas Binawan yang telah memberikan izin untuk kegiatan penelitian ini. Demikian pula untuk Ketua Laboratorium Pengolahan Pangan Institut Pertanian Bogor serta pihak-pihak terkait yang telah membantu dan memberikan dukungan dalam pelaksanaan penelitian ini.

\section{DAFTAR PUSTAKA}

Afrianti, F., Raswen F, dan Yusmarni. 2016. Pemanfaatan Pati Sagu Dan Tepung Kelapa Dalam pembuatan Kue Bangkit. Jom Faperta UR 3 (2): 1-16.

Hasan, Irma. 2018. Pengaruh Perbandingan Tepung Ampas Kelapa dengan Tepung Terigu Terhadap Mutu Brownies. Agriculture Technologi Journal 1 (1): 6067.

Herni, S., Tamrin dan Nur Asyik. 2018. Penilaian Organoleptik Serta Proksimat Biskuit Tinggi Serat Berbasis Tepung Kaopi Fermentasi dan Ampas Kelapa. Sulawesi Tenggara: Universitas Halu Oleo. Jurnal Sains dan Teknologi Pangan 3 (3): 1379-1392.

Indrati, Retno dan Murdijati Gardjito. 2013. Pendidikan Konsumsi Pangan. Jakarta: Kencana. 
Kailaku, Sari Intan, Ira Mulyawanti K.T.D., dan Andi N.A. 2012. Potensi Tepung Kelapa Dari Ampas Industri Pengolahan Kelapa. [Prosiding] Seminar Nasional Teknologi Inovatif Pascapanen Untuk Pengembangan Industri Berbasis Pertamina. 669-678.

Kusumaningrum, I., Mira. S, Leni, S.R. 2016. Pemanfaatan Ampas Sari Kacang Hijau Sebagai Sumber Serat Pada Pembuatan Brownies Berbahan Dasar Tepung Mocaf. Jakarta: Universitas Muhammadiyah Prof. Dr. Hamka.

Lubis, Y. M., Syarifah Rohaya dan Huri A. D. 2012. Pembuatan Meuseukat Menggunakan Tepung Komposit Dari Suku (Artocarpus altilis) dan Terigu Serta Penambahan Nenas (Ananas comosus L.). Jurnal Teknologi dan Industri Pertanian Indonesia 4 (2): 7-14.

Polii, Fahri Ferdinand. 2017. Pengaruh Substitusi Tepung Kelapa Terhadap Kandungan Gizi dan Sifat Organoleptik Kue Kering. Buletin Palma 18 (2): 91-98. Pusuma, D. A., Yulia, P., dan Miftahul C. 2018. Karakteristik Roti Tawar Kaya Serat yang Disubstitusi Menggunakan Tepung Ampas Kelapa. Jawa Timur: Universitas Jember. Jurnal Agroteknologi 12 (1): 29-42.

Putri, M. F. 2014. Kandungan Gizi dan Sifat Fisik Tepung Ampas Kelapa Sebagai Bahan Pangan Sumber Serat. Teknobuga 1 (1): 32-43.

Rousmaliana dan Septiani. 2019. Identifikasi Tepung Ampas Kelapa Terhadap Kadar Proksimat Menggunakan Metode Pengeringan Oven. Jurnal Ilmiah Kesehatan 1 (1): 18-31

Sari, M. L., A. L. M. Ali, S. Sandi, dan A. Yolanda. 2015. Kualitas Serat Kasar,
Lemak Kasar, dan BETN Terhadap Lama Penyimpanan Wafer Rumput Kumpal Minyak Dengan Perekat Karaginan. Palembang: Universitas Sriwijaya.

Setiawati, A., Rahimsyah, dan Ulyarti. 2015. Kajian Pembuatan Brownies Kaya Serat Dari Tepung Ampas Kelapa. Jambi: Universitas Jambi.

Suseno, Adi Agus. 2010. Pengaruh Perbandingan Tepung Terigu dan Tepung Biji Nangka Dalam Pembuatan Mie Basah Terhadap Komposisi Proksimat dan Daya Terima. [Skripsi] Surakarta: Universitas Muhammadiyah Surakarta.

Yulvianti. M., Widya Ernayati, Tarsono, dan M. Alfian R. 2015. Pemanfaatan Ampas Kelapa Sebagai Bahan Baku Tepung Kelapa Tinggi serat Dengan Metode Freeze Drying. Jurnal Integrasi Proses 5 (2): 101:107. 